\title{
GAMBLING AS THE TOURIST HABITUS
}

\author{
DOI: http://dx.doi.org/10.18509/GBP.2020.57 \\ UDC: 338.48-52:794.9]:303.725.3(497.11) \\ 338.48-52:794.9].01
}

\section{Vesna Miletić-Stepanović}

Faculty of Geography, University of Belgrade, Serbia

\begin{abstract}
The objectives of this paper are: theoretical and methodological development of a framework to study gambling as the tourist habitus, the empirical research on the network of casinos in Belgrade, and the secondary data analysis (Institute of Public Health, NGOs, tourism market research). Theoretically, the subject of our study - gambling as the tourist habitus, is observed from the context of the development process of the semi-peripheral chaotic city. The initial hypothesis is as follows: Through a developed network of casinos, the gambling industry promotes gambling as the tourist habitus, thereby on the one hand, generating the accumulation of economic capital, and on the other hand, causing mostly invisible social risks at the periphery of global capitalism. The systematic and negative impact of the gambling industry produces economic growth, favours the private interest of large capital, and from the society perspective it destroys public health, individuals' and families' health, increases social pathology conditions and addiction rate, exploitation of leisure time, crime, destabilizes marriage and family, impoverishes family, and causes violence against women. The theoretical framework includes the neo-Marxist theory by David Harvey, Manuel Castells and Henri Lefebvre, and the practice theory by Pierre Bourdieu. The empirical research was conducted based on the website presentations of the gambling houses, betting houses and casinos in Belgrade. This paper presents the results in accordance with the proposed network of indicators: the data confirm that the gambling industry produces economic growth, as well as numerous and devastating social consequences.
\end{abstract}

Key words: gambling industry, habitual gambling, social development, family

\section{INTRODUCTION}

The change in social norms about gambling has led to a change in the position and role of gambling in society - it used to be an illegal activity, while today it is legal and perceived as entertainment (Gaillard, 1993), as well as the legal and legitimate segment of the global tourism industry. This change in the perception of gambling produces ambivalent feelings about it: although gambling has been defined by the World Health Organization as an impulse control disorder and addiction, from the perspective of modern neoliberalism and the ideology of economic growth, gambling is seen as an expanding industry, and a growing sector in Europe (Alice Rap, 2013). Moreover, gambling has negative social consequences that are exacerbated in vulnerable and unstable societies: although this problem also exists in the multinational capital centres such as Canada or England, gambling has a greater negative impact on semi-peripheral societies, whose population is impoverished and unemployed, which is the case with Serbia. 


\section{LITERATURE REVIEW}

The gambling issue has been recognized and studied in projects at the EU level in order to perform the drug policy reform. The name of this project is ALICE RAP (Addiction and Lifestyles in Contemporary Europe - Reframing Addictions Project), whose results show that habitual gambling exists in Europe: people mostly gamble casually, almost 60$80 \%$ of the population gamble regularly; gambling activity is more present in men; [12], [14], [15], [16] however, the younger population as well as the middle class women are beginning to be more and more engaged in gambling activity (Reith, 2007). There is also a strong predisposition for excessive gambling, which leads to the impulse control disorder, and is called pathological or problem gambling (American Psychiatric Association, 1994; according to [13]). There has lately been an increase in the legal types of gambling in many countries, due to the public's positive attitude to gambling, who see gambling as a form of entertainment, as the industry that produces more jobs and increases national income, and it is in the interest of individual cities to strengthen tourism and economic development (Bjelde, Chromy and Pankow, 2008; according to [13]).

\section{THEORETICAL APPROACH}

According to the neo-Marxist theory, the social and space reproduction occurs due to capital accumulation. The crucial idea proposed by Harvey [3], [5], Castells [2] and Lefebvre [7] is the concept of the Production of Space. The emphasis is on the role of space in the reproduction of capitalist relations. In the process of society reproduction, the habitus, which is the main concept in Pierre Burdieu's theory [1], is seen as the mediating term, and it represents subjective features, coercive experiences and dependence that are unconsciously embedded and inscribed into the patterns of everyday life and the use of tourism space. In this time of globalization, semi-peripheral Belgrade is strategically oriented towards the global market and the interests of multinational corporations, thus promoting a reductionist and functionalist strategy of city development [9], which leads to the contradiction between the economic growth and social development. The primary goal of post-socialist cities is to break barriers to market entry and to become competitive, which is reduced to deregulation. Post-socialist cities use the chaotic model of development [11], which leads to the radical differentiation of the economic and social spheres [10]. In regards to Belgrade development, the focus is on economic goals, European integration and foreign direct investment: strategic development depends on competitiveness, increase of financial resources, tax revenue, and favourable investment climate (SRBG, 2008:53). The city implements the "strategy of promoting urban consumption space and the city is presented as a place suitable for business and leisure", resulting in uncontrolled commercialization of urban space, reduced quality and number of public services and spaces, and the increase in sociospatial inequality [9].

\section{RESEARCH HYPOTHESES}

The aim of this paper is to develop a theoretical and methodological framework which is to be used to study gambling as the tourist habitus, and to conduct the empirical research on the network of casinos in Belgrade. The initial hypothesis: through a developed network of casinos, the gambling industry promotes gambling as the tourist habitus, thereby on the one hand, generating the accumulation of economic capital, and on the other hand, mostly invisible social risks at the periphery of global capitalism. The 
systematic and negative impact of the gambling industry produces economic growth, favours the private interest of large capital, and from the society perspective it destroys public health, individuals' and families' health, increases social pathology conditions and addiction rate, exploitation of leisure time, crime, destabilizes marriage and family, impoverishes family, and causes violence against women. Gambling is part of the habitual, imposed tourist habits, the patterns of everyday life, the use of tourist space that creates common tourist practices and coercion and addiction in leisure time. Gamblingbetting as the tourist habitus is a consequence of the systematic activity by the gambling industry (GI), and a reductionist and functionalist strategy of city development, and it thereby causes the collapse of the city's role as a permanent place of residence, and on the one hand, it triggers the creation of the risky city, and on the other hand the creation of the quasi-tourist space, quasi-leisure time and quasi-tourist city. The gambling industry participates in the (re)production of social inequalities and contradictions, as well as in the exploitation of the periphery, in two ways: on the one hand, the role of the city as a permanent place of residence is collapsing; its residential, educational, health, production, and leisure roles are also degrading; social pathological conditions and addictions start to develop, as well as the unfavourable patterns of socio-spatial development; the use value of the city space is decreasing, the poverty of families and households is increasing, as well as of crime, family instability, of the debt crisis risk, while the discrimination against women and gender inequality are on the rise. On the other hand, the quasi-tourism role of Belgrade as a city suitable for the gambling industry business is getting stronger: the quasi-tourist gambling role gradually overshadows the rest of the city roles, and the city becomes a quasi-tourist city, a city of tourist spectacle and tourist pseudo-events, and generates the production of social space adapted and subordinated to the needs of the global gambling industry.

The notion of habitus, perceived as socially-conditioned and imposed behaviour, is a link between the social reproduction of inequality, poverty and precariousness. In this way, the process of commodification and commercialization of urban space is strengthened the space is used to generate profit, there is no protection of the public interest, and no democratic cultural space of high use value exists; what is left is a gamblingized tourist space of high market value but also of high social risks.

\section{RESEARCH METHOD}

The goal of this paper is to develop the theoretical and methodological framework which is to be used to study gambling as the tourist habitus, as well as to conduct the empirical research on the network of casinos in Belgrade. However, the study of gambling as an industry and as a habitus is difficult in epistemological, theoretical and methodological terms for several reasons. First of all, there are no social studies on this topic, therefore, this is a pioneer research which has the opportunity to take the first steps in this field. Moreover, since gambling is still partly illegal and criminalized, it is difficult to obtain data as it is unsystematic and sparse. Furthermore, this is a relatively recent phenomenon in the restructured post-socialist society of Serbia. Due to all of the above facts, the data that is indirectly related to the phenomenon studied will be used very frequently. Data sources. Data from primary and secondary sources. The data from the primary sources are the original data directly collected for the first time for the purpose of studying this specific issue. Types of data - quantitative and qualitative (in the form of text, observation). 
Data sources: data from The Statistical Office of the Republic of Serbia, Institute of Public Health Batut, Tourism Development Strategy, Belgrade Development Strategy, NGO data, tourism market research. Indirectly collected data - the data available on the websites of the gambling associations, as well as on the portals of individual companies where gambling practices exist; newspaper articles related to the problem that is being studied. The collection, processing, analysis and synthesis of the data on the network of casinos in Belgrade were performed by the author of this paper during January 2020. The analysis included all of the casinos/betting houses/gambling houses in Belgrade, whose data can be found on the Internet.

Data analysis methods: the analysis of data from primary sources and secondary data analysis; critical analysis. Variables: For the purposes of this paper, a network of indicators was created, which is actually the proposal for the study of gambling from the sociological perspective. These indicators can be divided into three groups: indicators of tourism industry (TI) development, indicators of gambling industry (GI) development, and the indicators of gambling as the tourist habitus, including the negative consequences of habitual gambling. The indicators of tourism industry (TI) development: the number of tourists, number of employees that work in tourism industry, tourism revenue, foreign currency inflow from tourism. The indicators of gambling industry (GI) development: the institutionalization of the GI in Serbia, the estimated share of the GI revenue to the total tourism revenue, the estimated GI income, the GI network - casinos/betting houses/gambling houses, the number of GI employees, the number of casinos compared to the overall population. Gambling as the habitus: research on the consequences of gambling, estimated number of gamblers - estimated number of pathological gamblers addicts; efforts to organize and mobilize public institutions and NGOs to combat the consequences of gambling, reactions by the local community and civil society organizations, organized tourist visits for gambling, the profile of tourists interested in GI, socially responsible GI business; social consequences of gambling - young people and children start to engage in habitual gambling, divorces, violence against women, destruction of individuals and families public health, destabilization of marriage and family, crime.

\section{RESULTS AND DISCUSSION}

\section{Tourism industry}

Being one of the most dynamic industries in the world, tourism is in line with Belgrade's efforts to "be competitive with European cities" [17]. Belgrade's tourism industry is perceived as an emerging industry, including the inevitable betting houses, which have become the only "factories" that generate revenue $\{1\}$. Belgrade intends to retain the image of the tourist city, therefore, the investment in the tourism industry is the backbone of the city's development strategy, given that "Belgrade's revenue depends on tourism" $\{2\}$. The studies on tourist arrivals and overnight stays in Belgrade show an increase in foreign tourist visits and overnight stays after the year 2000 [8], which is when the legalization of the gambling market and the institutionalization of the gambling industry started. These two events can be linked and viewed as indicators of the two mutually conditioned phenomena - the development of the tourism and gambling industry. In 2017, tourism revenue in Serbia was 1.2 billion euros (almost $\$ 1.5$ billion), with the capital city generating around 750 million euros off this amount, which is around $60 \%$ of its total revenue, according to the data available to the Tourist Organisation of Belgrade and based 
on the data from the National Bank of Serbia $\{3\}$. The total foreign currency inflow from tourism in 2015 was $\$ 1.048$ million. Between 2007 and 2015, foreign currency inflow from tourism increased by $97.4 \%$, with an average annual growth rate of $108 \%$.

\section{Gambling industry}

The institutionalization of the gambling industry and the legalization of the gambling market in Serbia: The games of chance are treated as a type of entrepreneurship, and the Games of Chance Act was passed in 2004. According to the scarce data available, the estimated revenue from gambling tourism in Serbia in 2015 was $\$ 500$ million $\{4\}$. Moreover, the data available do not allow us to estimate how much of this $\$ 500$ million amount was the inflow by foreign citizens, and how much by the citizens of Serbia.

Due to the high income from tourism in Serbia, there is a strategic orientation towards the gambling market and the interests of gambling corporations, that is, the promotion of the reductionist and functionalist development strategy not only of the city of Belgrade, but also of mountain tourism centres such as Tara, Golija and Uvac $\{5\}$. According to the Serbia Association of Gaming Organizers, Serbia is in the $19^{\text {th }}$ position in Europe based on the number of legal casinos compared to the total population $\{6\}$. There is no official data on casino revenues, which is partly due to the connection between crime and gambling industry. However, according to the official statements by Tourism Ministry employees in 2017, domestic casinos revenue accounts for a fifth of the total tourism revenue $\{7\}$, which is due to the fact that foreigners come to Belgrade in organized groups to gamble $\{8\}$. According to the data from the Ministry of Finance - The Games of Chance Administration department published in the Progress Report, which was updated on $14^{\text {th }}$ January 2020, as of $31^{\text {st }}$ December 2005, there are 31,305 slot machines in Serbia, and 2,110 pay-out betting and gambling sites.

According to the data of the Statistical Office of Serbia from 31/01/2020 \{9\}, out of the total of 2,202,635 people employed, there are 10,616 people working in the "betting and gambling" industry, meaning that the number of employees that work in the institutionalized gambling industry is the same as one third of agricultural workers $(31,000)$, more than one third of those employed in oil and gas exploitation $(26,409)$, slightly more than the number of people that work in the coal industry $(13,757)$, almost the same as the mining industry $(10,652)$, around three times more than the number of people working in Srbijagas $(3,988), 40 \%$ more than the number of people working in the Oil Industry of Serbia $(6,120)$, twice more than the number of the Smederevo steel plant employees $(4,908)$, around $40 \%$ more than the number of people working in libraries, archives, museums and galleries $(6,859)$, more than there are people engaged in the creative, arts and entertainment activities $(9,803)$, more than the number of employees engaged in sports, entertainment and recreational activities $(10,081)$, and almost the same number of employees as in the scientific research and development $(10,567)$. However, the position of GI employees, as well as the position of the companies themselves is seen as unstable and risky in the banking market; in cases of loan approval they are considered high-risk clients $\{10\}$.

Cooperation between the GI and the institutions of society and city government is developing, as well as between the GI and educational institutions, student organizations, the labour market, and the GI is employing a significant portion of the relatively educated workforce. The educational structure of GI employees is also very specific - more than one third of these employees have university degree, and this number includes 100 IT professionals with the highest references. According to the data from the Serbia 
Association of Gaming Organizers, through their collaboration with other participants in the value chain - primarily suppliers - each direct GI employee collaborates with seven more jobs in other industries, which is a total of 91,000 jobs. If we include family members as well, that is around 365,000 people $\{11\}$. Of particular concern is the fact that the games of chance organizers engage in the development of software to support the games they organize, which is why they also collaborate with the eminent higher education institutions founded by the Government of the Republic of Serbia, and with student organizations. For example, Mozzart Company has a scholarship program for the most successful undergraduate and master's students and supports young talents, students of analytics, statistics, and software engineering. They also organize the "Career Path" program in order to introduce the students with the latest software solutions, modern marketing, statistical, analytical and other tools, and offer job opportunity for the best of them $\{12\}$.

The network of companies that organize games of chance in casinos/gambling houses/betting houses in Belgrade is seen as a commercialized - gamblingized space, more developed than the educational institutions: they include 2 state universities, and 201 elementary and 87 high schools $\{13\}$, and as many as 525 gambling establishments. The network, which is owned by 24 gambling and betting companies, for the most part includes the facilities that are part of the Mozzart betting company (130) $\{14\}$, as well as Maxbet (79) $\{15\}$, Meridian (70) $\{16\}$, Planet win 365 (48) $\{17\}$, Soccer (43) $\{18\}$, Admiral (24) $\{19\}$, Tas bet (27) $\{20\}$, Pin bet (28) \{21\}, Octagon bet (13) \{22\}, while less than 10 facilities are owned by Balkan bet $\{23\}$, Brazil bet $\{24\}$, Merkur $\{25\}$, Zerobet $\{26\}$, Macao $\{27\}$, Astra $\{28\}$, Game pub $\{29\}$, Coloseum bet $\{30\}$, Eldorado slot klub $\{31\}$, Winner club $\{32\}$, Eliot slot klub $\{33\}$, Revel slot klub $\{34\}$, and four by Casina $\{35\}$. From the aspect of the overall population, there is one casino in Belgrade on every 3162 inhabitants. In this way, the market space adapted and subordinated to the needs of the global gambling industry is developed, Belgrade is seen as a commodity in the gambling market, which further causes the collapse of the social space and the initial role of the city.

\section{Gambling as the habitus}

If data from the National Survey on Lifestyle of the Serbian Population - Use of Psychoactive Substances and Games of Chance are subjected to secondary analysis, we will obtain the data indicating a very dramatic practice and showing that gambling is the habitus, which causes addiction in the population between 18 and 64 years of age: the most common gambling activity is the lottery (lotto, bingo, scratch cards), almost every other resident of Serbia practices it from time to time, every third person during the past year, and $17.3 \%$ of the people over the past month. Sports betting is practiced by $17.2 \%$ of the population during their life, $13.1 \%$ engaged in it last year and $10 \%$ last month. Slot machines are used by $5.5 \%$ of the population over their lifetime. Lottery is an activity that all genders and age groups equally practice, while other forms of gambling are more common in the male population [6]. The high frequency of this practice supports the hypothesis that habitus exists, that is, this pattern of behaviour is widely present.

If we shift the focus from the actual gambling practice to the estimated number of addicts, the data is even more striking and speak of a strong collapse of public health and public interest, the collapse of the role of health in society: the analysis of the estimated number of addicts at the national level shows that $3.7 \%$ of the adult population in Serbia is at risk of some form of gambling, 1.1-2.0\% of them have a moderate and higher risk of gambling 
(problem gambling), and $0.3-0.7 \%$ of them are high-risk gamblers (pathological gambling). The data are subject to extrapolation to the population between 18 and 64 years of age, and it is estimated that between 51,000 and 93,000 people have gambling issues, with 14,000 to 33,000 of them being pathological gamblers. People who play certain casino games, on slot machines or online are at the greatest risk - approximately $50 \%$ of those who played some of these games over the past 12 months are at some risk of problem gambling [6]. According to a 2016 study, the Institute of Public Health found that there were around 45,000 pathological gamblers and those at serious risk of becoming one. Moreover, during the second semester of the 2017/18 school year, the Institute for Public Health conducted a survey on the health behaviour of school-age children as part of an international survey in 101 primary and secondary schools in Serbia, and obtained horrifying results, according to which almost every third high school student is a gambler $\{36\}$ ! This alarming information is related to the fact that there are many schools close to which it is very easy to open a casino, so the Protector of Citizens urged cities and municipalities in Serbia to increase the distance between the casinos and schools, and headlines appear in the newspaper saying "Poker during school recess" $\{37\}$, "They steal and borrow money to gamble" $\{38\}$. There is a medicalisation and psychologization of the gambling issue and its consequences, which is, paradoxically, part of the concept of socially responsible business of the gambling industry! The gambling industry itself, in collaboration with the Belgrade city government, is involved in this process: in April 2010, the Grand Casino Belgrade signed a protocol on collaboration with the City Assembly on the introduction of a call centre, an SOS line for pathological gamblers and other addictions, and on the project of pathological gambling prevention called "Gambling with life is not a game". The project assumes that gambling is an individual's issue: although eminent psychologists are involved, the problem is not presented as systemic. The Grand Casino website shows the research findings initiated by the City of Belgrade, as well as the SOS line number $\{39\}$. The initial hypothesis is also supported by the data provided by the association of hoteliers and restaurateurs of Serbia, according to which there are many tourists who come to Belgrade for gambling, mostly from Turkey, Israel, Greece, because in these countries this kind of entertainment is banned: while Turks and Israelis come in organized groups, Greeks, residents of the Republic of Srpska and Montenegro come individually $\{40\}$. The civil sector is also involved in solving the problem of habitual gambling with devastating consequences: a nongovernmental organization has been established - an SOS centre to help pathological gamblers and their families, according to which gambling is a growing mental health disease worldwide $\{41\}$. According to the NGO "Herc-Fund for the prevention of pathological gambling", 3500000 citizens in Serbia engage in some kind of gambling, encouraged by the State Lottery of Serbia and Radio Television of Serbia and Pink television $\{42\}$. It is estimated that one in five people who show an interest in gambling becomes a pathological gambler - which means that around 700000 Serbian citizens are at risk, which is considered to be a true "pathological gambling epidemic". According to the Day Hospital for Addiction Treatment, until a few years ago, most patients were alcohol addicts, while in recent years, the majority of patients (50\%) are pathological gamblers. Although the statistical data show that the ratio between men and women as pathological gamblers is 3:1, men actually make up $99 \%$ of the treated pathological gamblers at the clinic $\{43\}$. The social consequences of gambling are very negative and hardly visible, and mainly related to the collapse of public health, the health of individuals and families, the escalation of social pathological conditions and addiction, poverty, 
crime, marriage and family destruction, violence against women and children, risk of homelessness. According to the Gambling Prevention Fund data from 2009, 70 gamblers in Serbia owed a total of 1.5 million euros. The Pathological Gambling Prevention Fund is being addressed by people who owe tens of thousands of euros, and their gambling debts are growing at an enormous rate due to usurious interest rates and they cannot repay them. Furthermore, the number of crimes related to gambling debts is on the rise $\{44\}$. The civil Sector - that is, the "Um Sabac" Youth Association organized the gathering of signatures for a petition \{45\} in May 2019 against the gambling industry in Sabac, that is, to ban casinos and betting houses in the central part of the city $\{46\}$. Gambling as the habitus is also the cause of increasing divorce rates: since gambling is predominant among men, it disrupts family roles, endangers the existential position of families, resulting in divorce, so there are news articles saying that "Men from Jagodina lose their marriage due to poker and sports betting". Based on the data provided by the Centre for Social Work, couples from Jagodina are most often getting divorced recently because husbands spend money in the local betting houses and casinos, or at poker machines $\{47\}$, so in 2008 there was an increase in divorce rates by around 250\%. Habitual gambling is the cause of the most drastic forms of physical violence against women who have had to seek protection: According to the Women's Safe House, family budget spending patterns and the needs of a new-born child can reduce the amount of money a husband and father can use for gambling: "Ever since our son was born, he has become aggressive because most of the family budget is spent on the child" $\{48\}$, which is why losing in gambling can be the trigger for physical violence against the wife and children: "... if he had no luck in gambling, he would turn into a beast - he would break everything in the house and threaten to kill us. He once imagined that our son was bringing him "bad luck" because the child happened to be in the room when the football team he was betting on lost the game and he severely beat our son $\{49\}$ ". This paper primarily wants to emphasize the problematization of gambling as a phenomenon that also depends on the tourism industry, and affects the public health and family. The results of this paper are complementary to the domestic and foreign studies, however, unlike the previous studies, this research analyses this issue in the social context and analyses the hidden social consequences of economic growth.

\section{CONCLUSION}

In accordance with the research goal, the paper used a theoretical framework to study gambling as the tourist habitus, in the context of the critical neo-Marxist theory. Moreover, a system of indicators was developed as well, consisting of the indicators of tourism industry (TI) development, indicators of gambling industry (GI) development, and the indicators of gambling as the tourist habitus, and the negative consequences of habitual gambling. The hypothesis was confirmed that the gambling industry, through a developed network of casinos, turns gambling into the tourist habitus, thus generating economic growth and accumulation of economic capital. On the one hand, it favours the private interests of large capital, while on the other hand it causes serious and mostly invisible social risks at the periphery of global capitalism - the addiction diseases, destruction of the public health of individuals and families, destabilization of marriage and family, it impoverishes family, causes violence against women, crime, and the exploitation of leisure time. The secondary data analysis supports the initial hypothesis: the economic growth happened as a result of the increase in arrivals and overnight stays of foreign tourists after 2000, as well as the legalization of the gambling market and the 
institutionalization of the gambling industry, growth in tourism revenues, where $60 \%$ of it comes from Belgrade; growth of total foreign currency inflow from tourism; high estimated revenue from the gambling industry (one fifth of total tourism revenue). There are 10,616 employees in the institutionalized gambling industry: 31,305 slot machines, and 2,110 pay-out betting and gambling sites. The empirical study of the network of casinos in Belgrade has revealed that there are as many as 525 facilities owned by 24 international companies. Habitual gambling is very prevalent - almost every other resident of Serbia played some kind of lottery in their lifetime, every third person did that during the past year, and $17.3 \%$ of the people over the past month. The economic growth that relies on the expansion of the gambling industry is influenced by the pattern of tourist movements: gambling as the tourist habitus is practiced by a large number of tourists, mostly from Turkey, Israel, Greece, who come in organized groups due to the restrictive gambling policies in these countries. Moreover, in Serbia, gambling as the tourist habitus is practiced by Greeks, people from the Republic of Srpska and Montenegro, but they come individually. Such economic growth causes addiction - there are between14,000 and 33,000 pathological gamblers, one in three high school students is a gambler, most patients at the day addiction hospitals are pathological gamblers. There is the escalation of social pathological conditions and addiction, crime, the increase in the already high rate of poverty, marriage and family destruction, violence against women and children, risk of homelessness. Gambling industry and gambling as the tourist habitus cause the exploitation of vulnerable and risky semi-peripheral households, and trigger the creation of the risky city, and on the other hand the creation of quasi-tourist space, quasi-leisure time and quasi-tourist city.

\section{Acknoligments}

The article is part of the project of THE NEW CHALLENGES OF SOCIAL INTEGRATION IN SERBIA - THE CHALLENGES AND THE STAKEHOLDERS, document number 179035, whose implementation the Ministry of Science and Technological Development of Republic of Serbia

\section{REFERENCES}

[1] Burdje, P: Nacrt za jednu teoriju prakse: tri studije o kabilskoj etnologiji, Beograd: Zavod za udžbenike i nastavna sredstva, 1999.

[2] Castells, M.: The Urban Question. A Marxist Approach. London: Edward Arnold, 1977.

[3] Harvey D.: The Limits of Capital, Oxford: Blackwell, 1982.

[4] Harvey, D.: The Condition of postmodernity, Oxford: Blackwell, 1989.

[5] Harvey, D.: The Condition of Postmodernity, Oxford: Blackwell, 1990.

[6] Институт за јавно здравље др Милан Јовановић Батут: Национално истраживање о стиловима живота становништва Србије - коришћење психоактивних супстанци и игре на cpehy, 2014.

[7] Lefebvre, H: The Production of Space, Blackwell, Oxford, 1991.

[8] Милетић, Ј.: Промет туриста у Београду, у: Земља и људи, Српско географско друштво, Београд, pp 71-7, 2017.

[9] Miletić-Stepanović V.: Protivrečnosti socio-prostornog razvoja Beograda: retradicionalizacija porodice kao poluperiferni urbani habitus, Univerzitet, Geografski fakultet, Beograd, 2014.

[10] Petrović, M. : Transformacija gradova: ka depolitizaciji urbanog pitanja, Institut za sociološka istraživanja Filozofskog fakulteta - Čigoja, Beograd, 2009, 
[11] Stanilov, K.: "Taking stock of post-socialist urban development: A recapitulation." u: Kiril S. (ed.). The Post-Socialist City: Urban Form and Space Transformations in Central and Eastern Europe after Socialism. Dordrecht: Springer: pp. 3-21, 2007.

[12] Shinogle, J., Norris, D. F., Park, D., Volberg, R. A., Haynes, D., Stokan, E.: Gambling Prevalence in Maryland: A Baseline Analysis. Report to the Maryland Department of Health\&Mental Hygiene. Baltimore, MD: Maryland Institute for Policy Analysis\&Research, 2011. http://mipar.umbc.edu/files/2015/01/Finalgambling.pdf

[13] Tse, S., Hong, S.I., Wang, C.W., \& Cunningham-Williams, R.M. : Gambling behavior and problems among older adults: a systematic review of empirical studies. Journals of Gerontology Series B: Psychological Sciences and Social Sciences, 67 (5), pp. 639-652, 2012.

[14] Welte, J. W., Barnes, G. M., Wieczorek, W. F., Tidwell, M.-C. O., Parker, J. C.: Risk factors for pathological gambling. Addictive Behaviors, 29 (2), pp. 323-335, 2004.

[15] Wardle, H., Seabury, C., Ahmed, H., Payne, C., Byron, C., Corbett, J., Sutton, R.: Gambling Behavior in England and Scotland: Findings from the Health Survey for England 2012 and Scottish Health Survey 2012. Prepared for: The Gambling Commission, 2011. http://prism.ucalgary.ca/bitstream/1880/50217/1/Gambling_behaviour_England_Scotland_2012 _Survey.pdf

[16] Welte, J. W., Barnes, G. M., Tidwell, M-C. O., Hoffman, J. H., Wieczorek, W. F. : Gambling and problem gambling in the United States: Changes between 1999 and 2013. Journal of Gambling Studies, 31, pp. 695-715, 2015.

[17] Влада Републике Србије Министарство трговине, туризма и телекомуникација: Стратегија развоја туризма 2016-2025, Београд, 2016.mtt.gov.rs > STRATEGIJA RAZVOJA TURIZMA RS 2016-2025http://www.uis.gov.rs/index.php?\&lng=cyr

[18] http://www.uis.gov.rs/spisak-priredjivaca.php?\&lng=cyr

[19] https://grandcasinobeograd.rs/\#/

[20] https://grandslotclub.rs/

\section{DATA SOURCES:}

$\{1\}$ http://www.politika.rs/sr/clanak/351009/Region/Evropski-rekorder-po-broju-kladionica

$\{2\}$ https://www.danas.rs/beograd/beograd-zivi-od-turizma/

\{3\} http://www.politika.rs/sr/clanak/395271/Beograd/Od-turizma-zarada-oko-750-miliona-evra

$\{4\}$ https://www.vesti-online.com/kockari-hrle-u-beograd/

$\{5\}$ Ibid.

$\{6\}$ https://www.021.rs/story/Info/Srbija/141945/Kladionica-drzavi-profitabilna-a-od-gradjanapravi-zavisnike.html

$\{7\}$ https://www.vesti-online.com/kockari-hrle-u-beograd/

$\{8\}$ Ibid.

\{9\} RZS Саопштење број 1631.012020

$\{10\}$ https://www.ekapija.com/news/1609431/banke-izbegavaju-davanje-kredita-radnicimarizicnih-firmi-zaposleni-u-kladionicama-i-kazinima

$\{11\}$ https://www.b92.net/biz/vesti/srbija.php?yyyy=2018\&mm=09\&dd=27\&nav_id=1448952

$\{12\}$ https://poslovi.infostud.com/poslodavac/mozzart-kladionica/586

$\{13\}$ https://www.beograd.rs/m/zivot-u-beogradu/1006-obrazovanje-i-nauka/

$\{14\}$ https://www.mozzartbet.com/sr\#/ 
$\{15\}$ https://www.maxbet.rs

$\{16\}$ https://meridianbet.rs/promo/casino-300-

$\{17\}$ https://av.365.rs/bet

$\{18\}$ https://soccerbet.rs

$\{19\}$ https://admiralclub.rs

$\{20\}$ https://www.tas-bet.com/kompanija

$\{21\}$ http://pinnbet.rs

$\{22\}$ https://www.oktagonbet.com

$\{23\}$ https://www.balkanbet.rs

$\{24\}$ https://www.brazil.rs

$\{25\}$ http://www.merkurautomatklub.rs

$\{26\}$ http://www.zerobet.com

$\{27\}$ www.macaoslotclub.com

$\{28\}$ otkucaji-grada.rs/sr/lokaliteti/detalji/8999/astra-slot-club

$\{29\}$ https://gamepub.rs

$\{30\}$ http://www.colosseumbet.com

$\{31\}$ https://eldoradoslotclub.rs

$\{32\}$ http://winnerclub.rs

$\{33\}$ https://eliteslotclub.rs

$\{34\}$ https://www.facebook.com/RevelSlotClub/

$\{35\}$ https://grandcasinobeograd.rs/\#/ , http://casinofairplay.rs/

$\{36\}$ https://www.republika.rs/vesti/drustvo/173722/porazavajuci-rezultati-istrazivanja-institutabatut-svaki-treci-srednjoskolac-kockar

\{37\}https://www.novosti.rs/vesti/naslovna/drustvo/aktuelno.290.html:271584-Poker-navelikom-odmoru

$\{38\}$ https://www.blic.rs/vesti/drustvo/kocka-kladionice-srbija/tx3hz06

$\{39\}$ https://grandcasinobeograd.rs/\#/

$\{40\}$ https://www.vesti-online.com/kockari-hrle-u-beograd/

\{41\}http://www.mc.rs/osnovan-je-sos-centar-za-pomoc-patoloskim-kockarima-i-njihovimporodicama. 4 .html?eventId $=7368$

$\{42\}$ http://www.kockanje.org/

$\{43\}$ http://www.lokalnenovine.rs/rubrike/drustvo/drs-09.12/clanak.php

$\{44\}$ http://www.mc.rs/osnovan-je-sos-centar-za-pomoc-patoloskim-kockarima-i-njihovimporodicama.4.html?eventId $=7368$

\{45\}http://www.sabac.tv/vesti/26746/prikupljanje-potpisa-za-izmestanje-kladionica-ikockarnica

\{46\} https://www.glaspodrinja.rs/cir/vesti/15258/mali-pariz-a-ne-las-vegas/

$\{47\}$ http://www.politika.rs/sr/clanak/97669/Srbija/Na-pokeru-i-tiketu-Jagodinci-gube-brakove

$\{48\}$ http://www.politika.co.rs/sr/clanak/368711/Zbog-gubitka-na-kocki-krvnicki-je-pretukao-imene-i-dete

$\{49\}$ Ibid. 